\title{
Structural studies on membrane-bound bovine rhodopsin
}

\author{
Eric MULLEN and Muhammad AKHTAR \\ Department of Biochemistry, University of Southampton, Bassett Crescent East, Southampton SO9 3TU, U.K.
}

(Received 2 A ugust 1982/Accepted 10 December 1982)

\begin{abstract}
Our previous work has shown that the treatment of bovine rhodopsin with the proteolytic enzyme papain gives rise to a cleaved, but fully functional, complex consisting of three fragments, H, M and L (heavy, medium and light), held together by strong non-covalent forces. By using some of the chemical and physical differences between the three fragments, a protocol for the preparative isolation of each fragment was devised. Purified M-fragment, which had been radiochemically labelled at the retinal-binding site was treated with $\mathrm{CNBr}$ and the mixture subjected to a multi-step separation to furnish a retinyl peptide. The sequence analysis of the latter showed that the retinal-binding lysine residue was located at position 296 from the $N$-terminal of rhodopsin (or residue 53 from the $C$-terminal). In order to ascertain the position of the cytoplasmic loop which exists between the $M$ - and L-fragments, radiochemically labelled L-fragment was isolated from the cleaved complex. The purified L-fragment was shown to consist of two populations of peptides which were produced by the action of papain on the bonds between Lys-311 and Gln-312 and between Gln-312 and Phe-313.
\end{abstract}

Rhodopsin, the photosensitive pigment found in the rod outer segments of the retina, consists of a glycoprotein, opsin, covalently bound to 11-cisretinal via a Schiff base linkage to the $\varepsilon$-amino group of a lysine residue (Akhtar et al., 1965, 1967, 1968; Bownds, 1967). Light activation isomerizes the retinal chromophore from the 11-cis to an all-trans form and this initiates spectrally defined changes in the rhodopsin that lead to visual excitation. In order to describe these processes in molecular terms a knowledge of the structure of rhodopsin and its organization in the membrane is required.

A technique specifically aimed at pin-pointing regions of rhodopsin that protrude from the membrane into the aqueous environment utilizes the limited proteolysis of ROS with papain (Trayhurn et al., 1974; Pober \& Stryer, 1975; Sale et al., 1977, 1978; Towner et al., 1977; Albert \& Litman, 1978). On the basis of such papain-cleavage experiments, Sale et al. (1977) proposed a model for rhodopsin that showed the molecule cleaved into three noncovalently linked fragments (heavy, medium and light). Continuing our studies on the structural analy-

Abbreviations used: h.p.l.c., high-pressure liquid chromatography; ROS, rod outer segments; NEM, $N$-ethylmaleimide; SDS, sodium dodecyl sulphate; h.v.p.e., high-voltage paper electrophoresis; Hse, homoserine; CmCys, carboxymethylcysteine. sis of rhodopsin we now describe methods for the isolation of these three fragments of papain-cleaved rhodopsin, report on the location of the retinalbinding lysine residue and identify one region of the polypeptide chain between the $\mathrm{M}$ - and L-fragment which protrudes from the membrane into the interdiscal space. This work is based on a Ph.D. Thesis (Mullen, 1982), and some of the experiments herein have been described in a preliminary communication (Mullen \& Akhtar, 1981).

\section{Experimental and results}

\section{Materials}

Cattle eyes were collected at an abattoir within $10 \mathrm{~min}$ of the animals' deaths. The retinas were removed immediately and stored in a light-proof flask. They were either processed on arrival at the laboratory or stored in the dark at $4^{\circ} \mathrm{C}$ for processing the following day. $\mathrm{NaB}^{3} \mathrm{H}_{4}$, iodo[2- $\left.{ }^{3} \mathrm{H}\right]-$ acetic acid and $N$-ethyl $\left[2,3-{ }^{14} \mathrm{C}\right]$ maleimide were obtained from The Radiochemical Centre, Amersham HP7 9LL, Bucks., U.K. Concanavalin ASepharose 4B, LH60-120 Sephadex and papain were from Sigma (London) Chemical Co., Kingston upon Thames KT2 7BH, Surrey, U.K. Ammonyx LO [an aq. $30 \%(w / v)$ solution of dodecyldimethylamine oxide/tetradecyldimethylamine oxide 
(13:7, w/w)] was from Venture Chemicals, Reading, Berks., U.K. Vitamin A aldehyde (retinal) was from Fluorochem Ltd., Glossop SK13 9NU, Derbyshire, U.K. and CM32 cellulose and 3MM chromatography paper were from Whatman, Maidstone ME14 2LE, Kent, U.K. All other reagent-grade chemicals were from BDH Chemicals Ltd., Poole BH12 4NN, Dorset, U.K. Ethanol and distilled water for h.p.l.c. were further distilled in glass apparatus. Acetonitrile for the h.p.l.c. was obtained from Rathburn Ltd., Walkerburn, Peeblesshire, Scotland, U.K.

\section{Preparation of ROS}

Freshly collected bovine retinas $(60-100)$ were vigorously shaken in $45 \%(\mathrm{w} / \mathrm{v})$ sucrose $(1 \mathrm{ml} /$ retina) and then processed essentially as described by Sale et al. (1977). ROS, found at the $34 / 36 \%$ interface of a discontinuous sucrose gradient, were removed with a syringe, diluted fourfold with the buffer, collected by centrifugation at $40000 \mathrm{~g}$ for $30 \mathrm{~min}$ and washed three times in water by suspension and centrifugation. This isolation procedure routinely yielded $19-29 \mathrm{nmol}$ of rhodopsin per retina (measured from $\varepsilon_{500} 40000 \mathrm{~mol} \cdot \mathrm{litre}^{-1} \cdot \mathrm{cm}^{-1}$; Applebury et al., 1974). The ROS had $A_{280} / A_{500}$ ratios of 2.2-2.6.

\section{Domain-specific labelling of papain-cleaved rhodopsin}

Labelling with $\left[{ }^{3} \mathrm{H}\right]$ retinal. ROS containing rhodopsin $(1.24 \mu \mathrm{mol})$ were bleached and then regenerated with a 2-fold molar excess of 11cis $-\left[15-{ }^{3} \mathrm{H}\right]$ retinal (prepared as described by Akhtar et al., 1968; sp. radioactivity $5.6 \times 10^{6}$ d.p.m./ $/ \mu \mathrm{mol}$ ) as described by Sale et al. (1977). Regeneration, as measured by the reappearance of the $A_{500}$ band of rhodopsin, was $100 \%$.

The regenerated material was cleaved with papain under the conditions described by Trayhurn et al. (1974) as described by Sale et al. (1977). No loss of $A_{500}$ occurred during proteolysis.

$A$ portion of the papain-cleaved material $(150 \mathrm{nmol})$ was suspended in water $(75-100 \mathrm{nmol} /$ $\mathrm{ml}$ ) and irradiated in the presence of $\mathrm{NaBH}_{4}$ $(1.5 \mathrm{mg} / 25 \mathrm{nmol}$ of rhodopsin) to fix the label to the protein as the stable $N$-retinyl derivative $\left(\left[{ }^{3} \mathrm{H}\right]-\right.$ retinyl-opsin). The fixed material was collected by centrifugation. Non-fixed $\left[{ }^{3} \mathrm{H}\right]$ retinal was removed by washing the pellet twice in aq. $80 \%(v / v)$ methanol and once in water. A sample of papaincleaved $\left[{ }^{3} \mathrm{H}\right]$ retinyl-opsin $(25 \mathrm{nmol})$ was worked up as described by Mullen et al. (1981) to determine a stoichiometry of incorporation of $1.02 \mathrm{~mol}$ of retinal/ mol of opsin.

Labelling with $\left[{ }^{14} \mathrm{C}\right] N E M$. ROS were suspended in $200 \mathrm{~mm}$-potassium phosphate buffer, $\mathrm{pH} 7.0$ (50$100 \mathrm{nmol} / \mathrm{ml}$ ), and incubated with a 20 -fold molar excess of $N$-ethyl[2,3-14 $\mathrm{C}]$ maleimide $\left(\left[{ }^{14} \mathrm{C}\right] \mathrm{NEM}\right.$, sp. radioactivity $1.7 \times 10^{6}$ d.p.m. $/ \mu \mathrm{mol}$ ) for $18 \mathrm{~h}$ at room temperature with gentle shaking. The labelled rhodopsin in ROS was then collected by centrifugation and washed twice in $67 \mathrm{~mm}$-potassium phosphate buffer, $\mathrm{pH} 7.0$. The $\left[{ }^{14} \mathrm{C}\right] \mathrm{NEM}$-labelled rhodopsin $(250 \mathrm{nmol})$ was cleaved with papain and washed. The stoichiometry of incorporation in a sample of the protein was calculated to be $2.0 \mathrm{~mol}$ of $\left[{ }^{14} \mathrm{C}\right] \mathrm{NEM} / \mathrm{mol}$ of rhodopsin (see also de Grip et al., 1975).

Carboxymethylation and analysis of variously labelled cleaved-rhodopsin samples

Papain-cleaved $\left[{ }^{14} \mathrm{C}\right] \mathrm{NEM}$-labelled rhodopsin $\left(52.6 \mathrm{nmol}, 1.79 \times 10^{5}\right.$ d.p.m. $)$ was added to papaincleaved $\left[{ }^{3} \mathrm{H}\right]$ retinyl-opsin $\left(95.4 \mathrm{nmol}, \quad 5.3 \times 10^{5}\right.$ d.p.m.) in $1 \mathrm{ml}$ of water and the protein was carboxymethylated with iodoacetic acid and re-isolated as described by Mullen \& Akhtar (1981).

A sample of the carboxymethylated material $\left(4.72 \mathrm{nmol} ; 5.9 \times 10^{3}\right.$ d.p.m. of ${ }^{14} \mathrm{C}, 1.8 \times 10^{4}$ d.p.m. of ${ }^{3} \mathrm{H}$ ) was solubilized and analysed by SDS/ 15\%-polyacrylamide-gel electrophoresis. The gel was stained for protein with Coomassie Blue. Three bands of apparent mol.wts. 23000, 15500 and 6000 were identified (Fig. 1a). The electrophoresis gel was sliced into $2 \mathrm{~mm}$-thick discs, which were used for the determination of radioactivity. All of the ${ }^{3} \mathrm{H}$ label originally associated with 11 -cis- $\left[15-{ }^{3} \mathrm{H}\right]$ retinal comigrated with the $\mathrm{M}$-fragment (Fig. $1 b$ ), $56 \%$ $\left(3.3 \times 10^{3}\right.$ d.p.m.) of the ${ }^{14} \mathrm{C}$ label was found in the $\mathrm{H}$-fragment and $41 \%\left(2.4 \times 10^{3}\right.$ d.p.m. $)$ of ${ }^{14} \mathrm{C}$ was found in the L-fragment (Fig. 1c).

\section{Preparation of the three fragments of papain-cleaved rhodopsin}

The preceding mixture $\left(75 \mathrm{nmol}, 9.35 \times 10^{4}\right.$ d.p.m. of ${ }^{14} \mathrm{C}, 2.85 \times 10^{5}$ d.p.m. of ${ }^{3} \mathrm{H}$ ) was dissolved in $5 \mathrm{~mm}$-potassium phosphate buffer containing $3 \%$ $(w / v)$ Ammonyx LO, pH $5.0(2 \mathrm{ml})$ and applied to a column $(0.5 \mathrm{~cm} \times 4 \mathrm{~cm})$ of CM-cellulose, previously equilibrated in the buffer. The column was washed with the buffer $(50 \mathrm{ml})$. All of the ${ }^{3} \mathrm{H}$ radioactivity $\left(2.5 \times 10^{5}\right.$ d.p.m. $)$ and $54.7 \%$ of the ${ }^{14} \mathrm{C}$ radioactivity $\left(5.1 \times 10^{4}\right.$ d.p.m. $)$ was eluted from the column in seven fractions $(1.5-10 \mathrm{ml})$ (Fig. $2 a$ ). This material corresponded to the $\mathrm{M}$ - and $\mathrm{H}$-fragments. The material remaining on the column was eluted with $500 \mathrm{mM}$-potassium phosphate buffer containing $3 \%$ $(\mathrm{w} / \mathrm{v})$ Ammonyx LO, $\mathrm{pH} 7.0(50 \mathrm{ml})$. The remainder of the ${ }^{14} \mathrm{C}$ radioactivity $\left(3.7 \times 10^{4}\right.$ d.p.m.) was collected in seven fractions $(1.5-10 \mathrm{ml})$ (Fig. $2 b)$. When these fractions were pooled, dialysed against 2 litres of - water in Medicell dialysis-Visking tubing size $1-8 / 32$, freeze-dried and the protein washed with $80 \%(\mathrm{v} / \mathrm{v})$ methanol and then water, $13 \mathrm{nmol}$ $\left(2.2 \times 10^{4}\right.$ d.p.m.) of $\mathrm{L}$-fragment were obtained. 


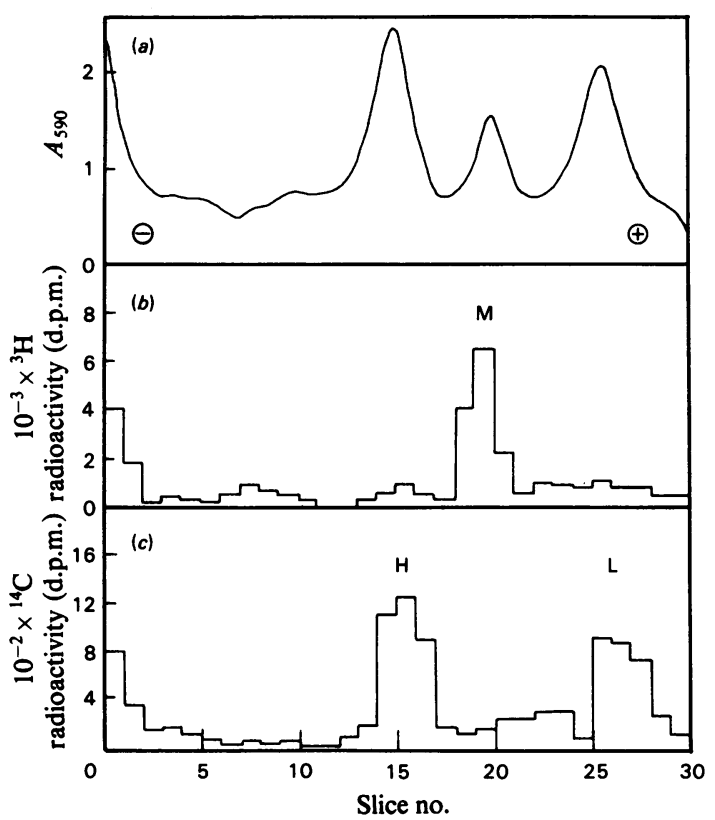

Fig. 1. SDS/polyacrylamide-gel electrophoresis of carboxymethylated papain-cleaved $\left[{ }^{14} \mathrm{C}\right] N E M$-labelled opsin and $\left[{ }^{3} \mathrm{H}\right]$ retinyl-opsin

Papain-cleaved $\left[{ }^{14} \mathrm{C}\right] \mathrm{NEM}$-labelled rhodopsin was added to papain-cleaved $\left[{ }^{3} \mathrm{H}\right]$ retinyl-opsin and the mixture carboxymethylated. A sample $(5.9 \times$ $10^{3}$ d.p.m. of ${ }^{14} \mathrm{C} ; 1.8 \times 10^{4}$ d.p.m. of $\left.{ }^{3} \mathrm{H}\right)$ was solubilized and subjected to SDS/polyacrylamide-gel electrophoresis. The gel was stained, scanned at $590 \mathrm{~nm} \mathrm{(a)}$ and sliced into $2 \mathrm{~mm}$-thick discs for the determination of ${ }^{3} \mathrm{H}$ radioactivity $(b)$ and ${ }^{14} \mathrm{C}$ radioactivity (c). H, M and $\mathrm{L}$ refer to heavy, medium and light fragments of rhodopsin.

The material corresponding to the $\mathbf{M}$ - and $\mathrm{H}$-fragments above (Fig. 2) was pooled, dialysed at room temperature, first against water (5 litre) and then against a solution of $50 \mathrm{~mm}-\mathrm{Tris} / \mathrm{HCl}$ containing $3 \%(\mathrm{w} / \mathrm{v})$ Ammonyx LO, $1 \mathrm{~mm}-\mathrm{MnCl}_{2}$, $1 \mathrm{mM}-\mathrm{CaCl}_{2}$ and $1 \mathrm{~mm}-\mathrm{MgCl}_{2}, \mathrm{pH} 7.0$ (2 litres) for 1h. The dialysis residue was applied to a column $(1 \mathrm{~cm} \times 4 \mathrm{~cm})$ of concanavalin A-Sepharose 4B previously equilibrated with the buffer. Upon washing with the buffer, $68 \%$ of the original ${ }^{3} \mathrm{H}$ radioactivity $\left(1.93 \times 10^{5}\right.$ d.p.m. $)$ and a negligible amount of ${ }^{14} \mathrm{C}$ radioactivity was eluted from the column (Fig. 3a). The fractions containing protein were pooled and worked up as described by Mullen \& Akhtar (1981). A total of $26 \mathrm{nmol}(1.48 \times$ $10^{5}$ d.p.m.) of M-fragment was obtained in this manner. The concanavalin A column was then washed with the buffer containing $250 \mathrm{~mm}$-methyl glucoside $(50 \mathrm{ml})$. The remainder of the ${ }^{14} \mathrm{C}$ radioactivity $\left(3.99 \times 10^{4}\right.$ d.p.m.) was eluted in $4.2-12.6 \mathrm{ml}$ of the buffer (Fig. 3b). After work-up, $15 \mathrm{nmol}$

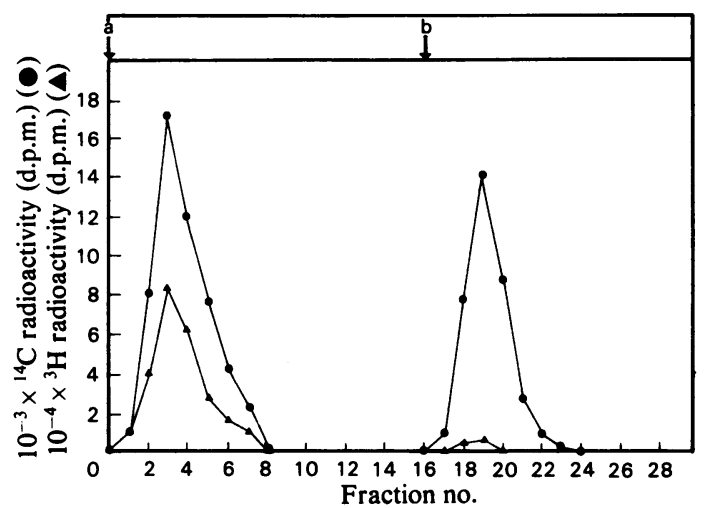

Fig. 2. CM-cellulose column chromatography of carboxymethylated papain-cleaved $\left[{ }^{14} \mathrm{C}\right] N E M$-labelled opsin and $\left[{ }^{3} \mathrm{H}\right]$ retinyl-opsin

A mixture of papain-cleaved $\left[{ }^{14} \mathrm{C}\right] \mathrm{NEM}$-labelled rhodopsin was added to papain-cleaved $\left[{ }^{3} \mathrm{H}\right]$ retinylopsin and the mixture carboxymethylated. The mixture $\left(9.35 \times 10^{4}\right.$ d.p.m. of ${ }^{14} \mathrm{C} ; 2.85 \times 10^{5}$ d.p.m. of $\left.{ }^{3} \mathrm{H}\right)$ was solubilized and applied to a column of CMcellulose. The column was washed with $5 \mathrm{~mm}$ potassium phosphate buffer, pH 5.0, containing detergent (a), and the remaining material was then eluted from the column with $500 \mathrm{~mm}$-potassium phosphate buffer, pH 7.0, containing detergent (b). Portions of each (approx. $1.5 \mathrm{ml}$ ) fraction collected were analysed for ${ }^{14} \mathrm{C}(O)$ and ${ }^{3} \mathrm{H}(\Delta)$ radioactivity.

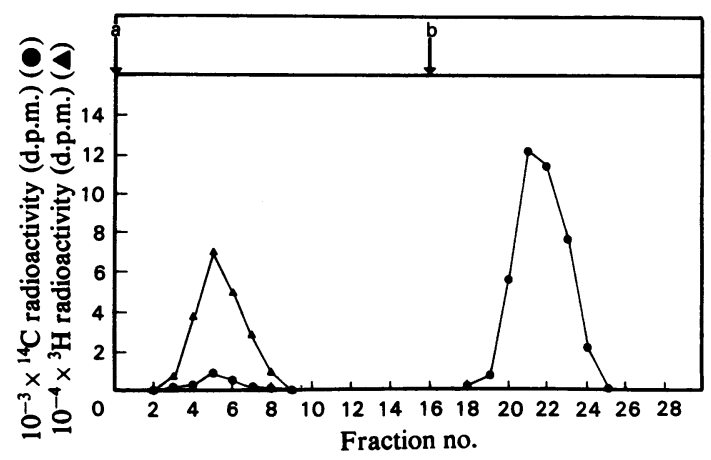

Fig. 3. Concanavalin A-Sepharose column chromatography of $H$-plus $M$-fragment

The fractions containing the $\mathrm{H}$ plus $\mathrm{M}$-fragments, eluted from the CM-cellulose column (Fig. 2, first peak) were pooled and worked up as described in the text. The mixture $\left(4.5 \times 10^{4}\right.$ d.p.m. of ${ }^{14} \mathrm{C} ; 2.2 \times 10^{5}$ d.p.m. of ${ }^{3} \mathrm{H}$ ) was then applied to a column of concanavalin A-Sepharose. The column was washed with a Tris buffer containing detergent $(a)$, and then with the Tris/detergent containing $\alpha$-methyl glucoside (b). Portions of each (approx. $1.5 \mathrm{ml}$ ) fraction collected were analysed for ${ }^{14} \mathrm{C}(\mathrm{O})$ and ${ }^{3} \mathrm{H}(\Delta)$ radioactivity. 


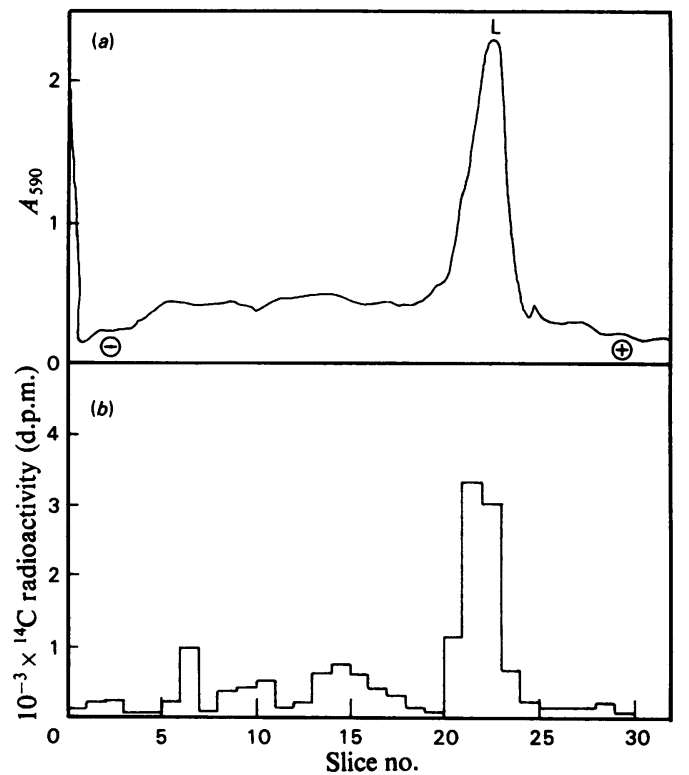

Fig. 4. SDS/polyacrylamide-gel electrophoresis of $\left[{ }^{14} C\right]$ NEM-labelled L-fragment from carboxymethylated papain-cleaved rhodopsin

A sample of $\mathrm{L}$-fragment $\left(5.2 \mathrm{nmol}, 9.0 \times 10^{3}\right.$ d.p.m.), isolated on a column of CM-cellulose, was subjected to SDS/polyacrylamide-gel electrophoresis as described in the text. The gel was stained, scanned at $590 \mathrm{~nm}(a)$ and sliced into $2 \mathrm{~mm}$-thick discs for the determination of radioactivity $(b)$.

(2.6 $\times 10^{4}$ d.p.m.) of $\mathrm{H}$-fragment were recovered. $\left[{ }^{14} \mathrm{C}\right] \mathrm{NEM}$-labelled L-fragment $\left(5.2 \mathrm{nmol}, 9.0 \times 10^{3}\right.$ d.p.m.). $\left[{ }^{3} \mathrm{H}\right]$ retinyl-M-fragment $\left(3.3 \mathrm{nmol}, 20 \times 10^{4}\right.$ d.p.m.) and $\left[{ }^{14} \mathrm{C}\right] \mathrm{NEM}$-labelled $\mathrm{H}$-fragment (5.0nmol, $8.6 \times 10^{3}$ d.p.m.) were each analysed by SDS/polyacrylamide-gel electrophoresis. Analysis of the gel of the L-fragment showed 69\% $\left(6.2 \times 10^{3}\right.$ d.p.m. $)$ of the applied radioactivity was associated with a single protein band of approx. mol.wt. 6000 (Figs. $4 a$ and $4 b$ ). The major peak on the gel of the $M$-fragment, corresponding to an apparent mol.wt. of 15500 , was associated with $72 \%\left(1.4 \times 10^{3}\right.$ d.p.m. $)$ of the applied radioactivity (cf. Figs. $5 a$ and $5 b$ ). Analysis of the gel of the $\mathrm{H}$-fragment showed a single protein band of apparent mol.wt. 23000. All of the applied radioactivity was found associated with this band (Figs. $6 a$ and $6 b)$.

\section{Preparation of the active-site peptide}

Isolation and purification. Rhodopsin in ROS $(1 \mu \mathrm{mol})$ was bleached, regenerated with $11-c i s-$ $\left[15-{ }^{3} \mathrm{H}\right]$ retinal (sp. radioactivity $5.0 \times 10^{6}$ d.p.m./ mol), cleaved with papain, and the radioactive label fixed to the protein as described above. The protein

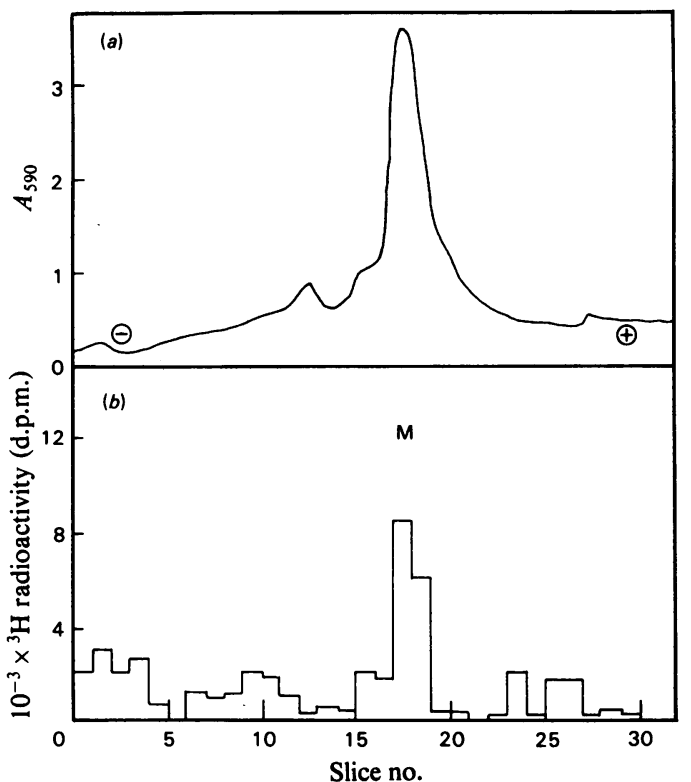

Fig. 5. SDS/polyacrylamide-gel electrophoresis of $\left[{ }^{3} \mathrm{H}\right]-$ retinyl-M-fragment $(M)$ from carboxymethylated papaincleaved rhodopsin

[ $\left.{ }^{3} \mathrm{H}\right]$ Retinyl-M-fragment was isolated by chromatography on columns of CM-cellulose and concanavalin A-Sepharose. A sample of the purified material $\left(3.3 \mathrm{nmol}, 20 \times 10^{3}\right.$ d.p.m.) was subjected to SDS/polyacrylamide-gel electrophoresis as described in the text. The gel was stained, scanned at $590 \mathrm{~nm}(a)$ and sliced into $2 \mathrm{~mm}$-thick discs for the determination of radioactivity $(b)$.

was then carboxymethylated and the stoichiometry of incorporation of the label calculated to be $1.03 \mathrm{~mol}$ of retinal $/ \mathrm{mol}$ of papain-cleaved opsin.

[ $\left.{ }^{3} \mathrm{H}\right]$ Retinyl-M-fragment $\quad\left(600 \mathrm{nmol}, 3.0 \times 10^{6}\right.$ d.p.m.) was then prepared from this material by chromatography on columns of CM-cellulose and concanavalin A-Sepharose as described previously. Upon analysis of a portion of the material by SDS/polyacrylamide-gel electrophoresis, all of the applied radioactivity was found associated with the major protein band corresponding to the $\left[{ }^{3} \mathrm{H}\right]$ retinyl-M-fragment (Fig. 5).

The $\mathrm{CNBr}$-cleaved fragments were subjected to a two-step separation involving h.v.p.e. and h.p.l.c. to yield $120 \mathrm{nmol}\left(6.1 \times 10^{5}\right.$ d.p.m.) of purified [ $\left.{ }^{3} \mathrm{H}\right]-$ retinyl-peptide. Not allowing for material taken for analysis at various stages in the purification, the overall yield of $\left[{ }^{3} \mathrm{H}\right]$ retinyl-peptide was $12 \%$ from $\left[{ }^{3} \mathrm{H}\right]$ rhodopsin and $20 \%$ from retinyl-M-fragment. The largest loss of material occurred at the elution of the retinyl-peptide from the paper in the electrophoresis step. A portion of the purified peptide 


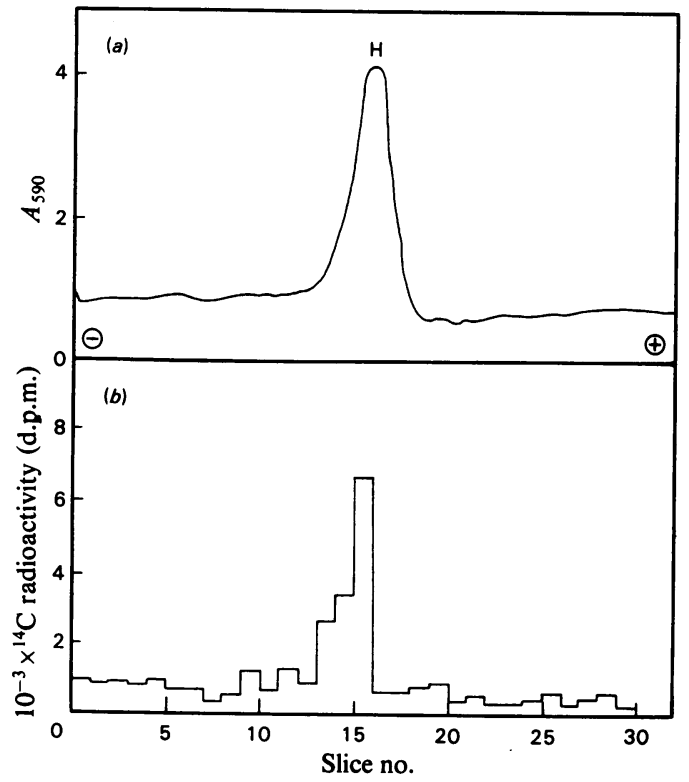

Fig. 6. SDS/polyacrylamide-gel electrophoresis of $\left[{ }^{14} \mathrm{C}\right] N E M$-labelled $H$-fragment $(H)$ from carboxymethylated papain-cleaved rhodopsin

A sample of $\mathrm{H}$-fragment (5.0nmol, $8.6 \times 10^{3}$ d.p.m.) isolated on a column of concanavalin A-Sepharose was subjected to SDS/polyacrylamide-gel electrophoresis as described in the Experimental section. The gel was scanned at $590 \mathrm{~nm}(a)$ and sliced into $2 \mathrm{~mm}$-thick discs for the determination of radioactivity (b).

$\left(25 \mathrm{nmol}, 1.2 \times 10^{5}\right.$ d.p.m. $)$ was hydrolysed overnight in the absence of oxygen with $6 \mathrm{M}-\mathrm{HCl}$ and analysed on a Rank-Hilger J80 automated amino acid analyser to yield the following amino acid composition: $\quad \mathrm{Asp}_{0.9} \mathrm{Thr}_{2.3} \mathrm{Ser}_{1.4} \mathrm{Glu}_{0} \mathrm{Pro}_{1.9} \mathrm{Gly}_{0.2^{-}}$ $\mathrm{Ala}_{3.3} \mathrm{Val}_{2.2}$ Met $_{0} \mathrm{Ile}_{3.0}$ Leu $_{0.1}$ Tyr $_{0.8}$ Phe $_{0.9}$ His $_{0}$ Lys $_{0.7^{-}}$ $\mathrm{Arg}_{0} \mathrm{Hse}_{0.5}$.

Sequence analysis. A further portion of the peptide $\left(25 \mathrm{nmol}, 1.2 \times 10^{5}\right.$ d.p.m.) was taken for sequence analysis by the method of Chang et al. (1978) as described by Mullen et al. (1981). The result of the sequence analysis is shown in Table 1.

A portion of the peptide $(44.5 \mathrm{nmol})$ was dissolved in formic acid $(0.5 \mathrm{ml})$ and ozone was passed through the solution at a rate of approx. $0.6 \mathrm{mg}$ of ozone $/ \mathrm{min}$ for $10 \mathrm{~min}$. Performic acid $(1 \mathrm{ml})$, freshly prepared by adding $\mathrm{H}_{2} \mathrm{O}_{2}(0.5 \mathrm{ml})$ to $98-100 \%$ formic acid $(9.5 \mathrm{ml})$ and leaving in a stoppered vessel for $2 \mathrm{~h}$ at room temperature, was added and the mixture was left for $30 \mathrm{~min}$ in an ice/water bath. The solution was then diluted with water $(10 \mathrm{ml})$ and freeze-dried. A $20 \mathrm{nmol}$ portion of this material was acid-hydrolysed and subjected to h.v.p.e. in pyridine/acetic acid/water $(1: 10: 289$, by vol.),
$\mathrm{pH} 3.5$, for $2.5 \mathrm{~h}$ at $2 \mathrm{kV}$. Then electrophoretogram was revealed with ninhydrin and $1 \mathrm{~cm}$ strips cut for the determination of radioactivity. The only radioactivity detected on the paper was found in the region that corresponded to the position of authentic $\varepsilon-N$-carboxymethyl-lysine, $8 \mathrm{~cm}$ from the origin towards the anode (Mullen et al., 1981).

\section{Purification of labelled L-fragment for sequence analysis}

Purification. The thiol groups on papain-cleaved rhodopsin $(1.3 \mu \mathrm{mol})$ were carboxymethylated by reaction with iodo $\left[2{ }^{3} \mathrm{H}\right]$ acetic acid (sp. radioactivity $1.96 \times 10^{6}$ c.p.m. $/ \mu \mathrm{mol}$ ) for $2 \mathrm{~h}$ and then an equal amount of non-radioactive iodoacetic acid for a further $2 \mathrm{~h}$. The carboxymethylated material $\left(470 \mathrm{nmol}, 5.5 \times 10^{6}\right.$ c.p.m. $)$ was isolated by precipitation as described above and dissolved in $5 \mathrm{~mm}$-potassium phosphate buffer containing $2 \%$ (w/v) dodecyldimethylamine oxide (prepared as described by Applebury et al., 1974), pH 5.0 (4 ml), for chromatography on CM-cellulose as described above. The resulting L-fragment $\left(2.5 \times 10^{6}\right.$ c.p.m. $)$ was chromatographed on a column $(2 \mathrm{~cm} \times 100 \mathrm{~cm})$ of Sephadex LH-60 equilibrated with $90 \%(\mathrm{v} / \mathrm{v})$ formic acid/ethanol $(3: 7, \mathrm{v} / \mathrm{v})$. Approx. $70 \mathrm{ml}$ of the eluant was discarded and fractions $(2 \mathrm{ml})$ were then collected, analysed for protein with ninhydrin and samples were taken for the determination of radioactivity. The elution profile of the peptide from the column showed a single radioactive ninhydrinpositive peak, which was eluted between 40 and $60 \mathrm{ml}$. The fractions containing radioactivity, which contained purified L-fragment, were evaporated under vacuum. A portion of the L-fragment $\left(4.0 \times 10^{4}\right.$ c.p.m. $)$ was analysed by SDS/polyacrylamide-gel electrophoresis to reveal a single protein band of apparent mol.wt. 6000 containing $75 \%$ of the applied radioactivity $\left(3.0 \times 10^{4}\right.$ c.p.m.).

L-peptide $\left(1.2 \times 10^{4}\right.$ c.p.m. $)$ was then subjected to h.p.l.c. on a Waters $\mu$-Bondapak $\mathrm{C}_{18}$ column previously equilibrated with aq. $0.3 \%$ trifluoroacetic acid/ethanolic $0.1 \%$ trifluoroacetic acid $(3: 2, \mathrm{v} / \mathrm{v})$. The peptide was eluted from the column with a linear gradient generated from solvent A [trifluoroacetic acid/ethanol/water, $0.1: 40: 60$ (by vol.)] and solvent B [trifluoroacetic acid/ethanol, 1:1000 (v/v)] over $30 \mathrm{~min}$ at a flow rate of $1.5 \mathrm{ml} / \mathrm{min}$. Samples $(100 \mu \mathrm{l})$ of each fraction $(1.5 \mathrm{ml})$ were used for the determination of radioactivity. A single peptide which contained $83 \%$ of the applied radioactivity $\left(1.0 \times 10^{4}\right.$ c.p.m. $)$ was eluted from the column at about $9 \mathrm{~min}$. The remainder of the L-fragment $\left(4.2 \times 10^{5}\right.$ c.p.m. $)$ was divided into two portions and each was run on the h.p.l.c. column. The eluted radioactive peaks were pooled $\left(3.6 \times 10^{5}\right.$ c.p.m. $)$ and evaporated under vacuum.

Purified L-fragment $\left(4.0 \times 10^{4}\right.$ c.p.m. $)$ was acid- 
Table 1. Amino acid sequence of the active-site peptide isolated from the $M$-fragment of $\left[{ }^{3} \mathrm{H}\right]$ retinyl-opsin The peptide ( $25 \mathrm{nmol}, 1.2 \times 10^{5}$ d.p.m.) was sequenced by the method of Chang et al. (1978). A portion of the coloured hydantoin derivative was used for the identification of the amino acid residue and the remainder for the determination of radioactivity. Abbreviation used: n.d., not determined.

$\begin{array}{ccc}\text { Turn no. } & \begin{array}{c}\text { Amino acid } \\ \text { identified }\end{array} & \begin{array}{c}\text { Radioactivity from } \\ \text { butyl acetate } \\ \text { extract (d.p.m.) }\end{array} \\ 1 & \text { Thr } & 245 \\ 2 & \text { Ile } & 120 \\ 3 & \text { Pro } & 170 \\ 4 & \text { Ala } & 200 \\ 5 & \text { Phe } & 205 \\ 6 & \text { Phe } & 185 \\ 7 & \text { Ala } & 185 \\ 8 & \text { n.d. } & 52518 \\ 9 & \text { Thr } & 3440 \\ 10 & \text { Ser } & 840 \\ 11 & \text { Ala } & 289 \\ \text { oactivity remaining in peptide } & \\ \text { after turn 11 (d.p.m.) } & \ldots & 3444\end{array}$

hydrolysed overnight and the amino acid composition calculated relative to the amount of alanine (=3.0) detected in the hydrolysate: Asp $_{3.4} \mathrm{Thr}_{5.3^{-}}$ $\mathrm{Ser}_{2.5} \mathrm{Glu}_{3.8} \mathrm{Pro}_{2.4} \mathrm{Gly}_{3.6} \mathrm{Ala}_{3.0} \mathrm{Val}_{2.4} \mathrm{Met}_{1.0} \mathrm{Ile}_{0.2} \mathrm{Leu}_{2.5}$ $\mathrm{Tyr}_{0} \mathrm{His}_{0} \mathrm{Lys}_{1.2} \mathrm{CmCys}_{1.7}$.

Sequence analysis. A portion of purified Lfragment $\left(2.9 \times 10^{4}\right.$ c.p.m. $)$ was treated with $0.2 \mathrm{M}$ $\mathrm{HCl}$ for $2 \mathrm{~h}$ at room temperature, freeze-dried and then subjected to sequence analysis by the method of Chang et al. (1978). The results showed that two residues were detected at each cycle and radioactivity, corresponding to carboxymethylcysteine, was released at turns 4 and 5 in the ratio of $2: 1$ (Table 2).

\section{Analysis by SDS/polyacrylamide-gel electrophoresis}

Samples of variously labelled proteins were solubilized and applied to gels prepared by the method of Swank \& Munkres (1971) containing $15 \%$ polyacrylamide, SDS, urea and $N N^{\prime}$ diallyltartardiamide. Electrophoresis, protein analysis and determination of radioactivity were carried out as described by Mullen et al. (1979).

\section{Discussion}

Our previous work has shown that when membrane-bound rhodopsin is treated in the dark with papain under carefully controlled conditions, a multiply cleaved but fully functional complex is produced (Sale et al., 1977). The cleaved complex, on non-reductive SDS/polyacrylamide-gel electro-
Table 2. Amino acid sequence of $L$-fragment from carboxymethylated papain-cleaved rhodopsin $\left[{ }^{3} \mathrm{H}\right]$ Carboxymethyl-L-fragment $\left(2.9 \times 10^{4}\right.$ c.p.m. $)$ was treated with $0.2 \mathrm{M}-\mathrm{HCl}$ and then sequenced as described in the Experimental and results section. A portion of the coloured hydantoin derivative was used for the identification of the amino acid residues and the remainder was used for the determination of radioactivity. Abbreviation used: $\mathrm{CmCys}$, carboxymethylcysteine.

$\begin{array}{ccc}\text { Turn no. } & \begin{array}{c}\text { Amino acid } \\ \text { identified }\end{array} & \begin{array}{c}\text { butyl acetate } \\ \text { extract (c.p.m.) }\end{array} \\ 1 & \text { Gln + Phe } & 135 \\ 2 & \text { Phe + Arg } & 142 \\ 3 & \text { Arg + Asn } & 182 \\ 4 & \text { Asn + CmCys } & 4076^{*} \\ 5 & \text { Met + Xaa } \dagger & 2035^{*} \\ 6 & \text { Met + Val } & 95 \\ 7 & \text { Val + Thr } & 103 \\ \text { Radioactivity remaining in peptide } & & 15921^{*} \\ \text { after final turn of sequence (c.p.m.) } & \ldots & 15\end{array}$

* The L-fragment contains three cysteine residues. Of the radioactivity originally associated with the peptide, $21 \%$ was removed at turns 4 and $5 ; 55 \%$ of the radioactivity remained with the peptide (see the text).

$\dagger$ CmCys was detected at turn 5 in insufficient yield to give a positive identification on the plate.

phoresis, shows three fragments (Fig. 1). Multiplelabelling techniques revealed that the fragments had originated from three discrete regions of the rhodopsin molecule. These species were designated $\mathrm{H}, \mathbf{M}$ and $\mathrm{L}$ (heavy, medium and light) fragments and were assigned the following features.

(1) The L-fragment had an estimated mol.wt. of about 6000 and was shown to contain three to four phosphorylation sites (Sale et al., 1978), a reactive thiol group (Sale et al., 1977) and the $C$-terminal portion of rhodopsin (Hargrave et al., 1980). It was hypothesized that the L-fragment represented one of the most hydrophilic regions of the rhodopsin molecule.

(2) The M-fragment with an approx. mol.wt. of 15500 had the retinal-binding site and was considered to reside between the $\mathrm{L}$ - and $\mathrm{H}$-fragments.

(3) The H-fragment, heaviest of the three species, contained the $N$-terminus, the two carbohydrate chains, the disulphide bonds, a second reactive thiol group modified by $N$-ethylmaleimide and other thiol groups which become available for modification only under denaturing conditions. It is also worth mentioning that the $\mathrm{H}$-fragment was cleaved between the disulphide loops, since reductive SDS/ polyacrylamide-gel electrophoresis resulted in the 
degradation of $\mathrm{H}$-fragment into three to four species, ranging in molecular weight from 4000 to 6000 .

\section{Isolation of the three fragments of papain-cleaved rhodopsin}

From the foregoing discussion it follows that, if the three fragments hitherto detected only by an electrophoretic technique could be separated on a preparative scale, they could provide information on the location of the retinal-binding site and other strategic domains in rhodopsin, and also be used for the determination of the regions of membrane-bound rhodopsin which protrude into the interdiscal phase. A rational approach for the separation of these fragments has now been designed and is based on the predicted hydrophilicity of the L-fragment and the presence of carbohydrate chains in the $\mathrm{H}$ fragment.

The first step in the separation strategy required masking the thiol groups of cleaved-rhodopsin by $S$-carboxymethylation under the denaturing conditions in which the protein could be maintained in a soluble state. This was conveniently achieved by performing the alkylation process in 1\% SDS at a protein concentration of $6 \mathrm{mg} / \mathrm{ml}$. It is our experience that precipitation of rhodopsin or its modified derivatives from detergent solutions invariably results in an irreversible aggregation of protein thus rendering the material unsuitable for structural work. In the present study, successful use of SDS in protein-modification experiments depended on the observation that the carboxymethylated fragments from papain-cleaved rhodopsin could be precipitated in an unaggregated form and then freed from the detergent by the addition of methanol under carefully defined conditions. The methodology emerging from this study is both rapid and applicable to the processing of small amounts of the protein material.

Samples of papain-cleaved rhodopsin, which were radioactively labelled by domain-specific reagents, were subjected to $S$-carboxymethylation by the procedure above. The modified fragments were solubilized in a buffer containing detergent and applied to a column of CM-cellulose. The $\mathrm{L}$ fragment was tightly bound to the column. The eluant containing the mixture of $\mathrm{H}+\mathrm{M}$-fragments, after appropriate work up, was applied to concanavalin-A-Sepharose. The carbohydrate-containing $\mathrm{H}$-fragment was retained on the column and the M-fragment was recovered in the void volume. The removal of detergent from the latter fraction yielded the M-fragment (Fig. 5). The purified $\mathrm{H}$-fragment was later eluted from the column of concanavalin A with a buffer containing $250 \mathrm{~mm}$ $\alpha$-methyl glucoside (Fig. 6). The L-fragment was eluted from the column of CM-cellulose with a high-ionic-strength high-pH buffer.

\section{Isolation of the retinyl-peptide from $M$-fragment}

In a recent publication (Mullen \& Akhtar, 1981) a sample of ROS containing rhodopsin labelled at the active site with $11-c i s-\left[15-{ }^{3} \mathrm{H}\right]$ retinal was cleaved with papain and the complex processed to yield a mixture of $\mathbf{M}$ - plus L-fragments which was used to obtain a homogeneous retinyl-peptide with the sequence:

Thr-Ile-Pro-Ala-Phe-Phe-Ala-Lys-Thr-Ser-Ala-Val-Tyr

$\begin{array}{lllllllllllll}1 & 2 & 3 & 4 & 5 & 6 & 7 & 8 & 9 & 10 & 11 & 12 & 13\end{array}$

These results have now been confirmed through the isolation of the same peptide from a purified sample of the M-fragment in 20\% yield and its analysis through eleven cycles of the Edman degradation. Of the radioactivity associated with the retinyl-peptide, $85 \%$ was released at the eighth cycle of Edman degradation (Table 1). Since in these experiments a direct identification of the coloured thiazolinone derivative of $\left[{ }^{3} \mathrm{H}\right]$ retinyl-lysine was not possible, the structural assignment was made by using an alternative approach. The $\left[{ }^{3} \mathrm{H}\right]$ retinyl-peptide was allowed to react with $\mathrm{O}_{3} / \mathrm{H}_{2} \mathrm{O}_{2}$ to convert the $N$-retinyl into an $N$-carboxymethyl-lysyl moiety (Mullen et al., 1981). A portion of the modified peptide was then hydrolysed and subjected to h.v.p.e. to show that all the radioactivity was associated with $\left[{ }^{3} \mathrm{H}\right]$ carboxymethyl-lysine. The cumulative evidence has confirmed the assignment of the active-site peptide to the $\mathrm{M}$-fragment.

The sequence of 83 amino acids from the $C$-terminal of bovine rhodopsin may be deduced from the structural information on two overlapping peptides already described in the literature and illustrated in Fig. 7. The 11 amino acids of the active-site peptide correspond to residues 60-50 from the $C$-terminal sequence, whereas the retinalbinding lysine residue is the 53rd amino acid from the $C$-terminus. In a previous study, alanylretinyllysine was isolated from a Pronase digestion of $\mathrm{NaBH}_{4}$-treated rhodopsin, and it was suggested to correspond to the Ala-Lys sequence present in the sequence found by Pellicone et al. (1980) (Wang et al., 1980) and subsequently assigned positions 54 and 53 from the $C$-terminus. We believe that the cumulative evidence described from our laboratory in the present paper and elsewhere (Mullen \& Akhtar, 1981) provide a direct, unambiguous and quantitative identification of the retinal-binding site in the partial sequence of bovine rhodopsin. After the acceptance of this paper for publication the complete amino acid sequence of bovine rhodopsin was reported by Ovchinnikov et al. (1982). In the light of this important new information the positions of the strategic residues identified in the present paper have been redefined and the active-site lysine residue may now be assigned position 296 from the $N$-terminus of rhodopsin (Fig. 7). 


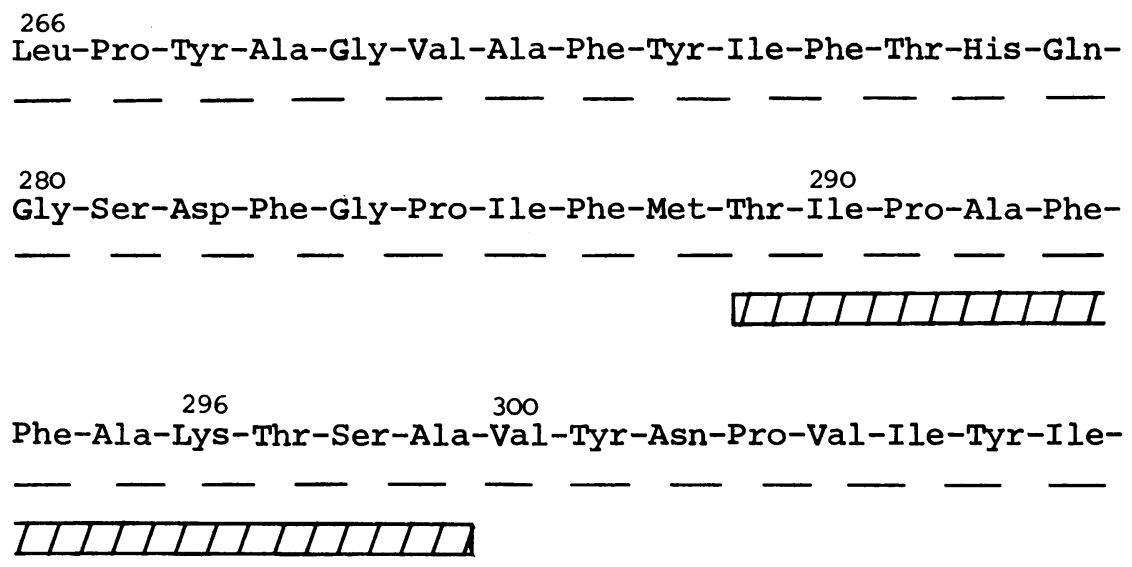

Met-Met-Asn-Lys-GIn-Phe-Arg-Asn-Cys-Met-Val-Thr-Thr-Leu-

पामामापामापम

330

Cys-Cys-Gly-Lys-Asn-Pro-Leu-Gly-Asp-Asp-Glu-Ala-Ser-Thr-

340

348

Thr-Val-Ser-Lys-Thr-Glu-Thr-Ser-Gln-Val-Ala-Pro-Ala

Fig. 7. Partial amino acid sequence of bovine rhodopsin showing the position of the active-site lysine residue (296) The peptides were sequenced by Hargrave et al. (1980) (-), Pellicone et al. $(1980,1981)(---)$ and in the present paper ( $\mathrm{mm}$ ). The numbering above is based on the complete amino acid sequence recently published (Ovchinnikov et al., 1982). The L-fragment has been shown to consist of two populations of peptides arising from the cleavage of the peptide bonds between Lys-311 and Gln-312, and Gln-312 and Phe-313.

The retinal-binding site in ovine rhodopsin has recently been reported (Findlay et al., 1981, 1982) and has been shown to be also localized at the 53rd position from the $C$-terminus. A comparison between the sequences of the peptides obtained from the bovine and ovine rhodopsins shows an interesting variation in the amino acid residues after the active site. The present work shows the three post-activesite (lysine) residues to be Thr-Ser-Ala and the sequence is in complete agreement with that described by Pellicone et al. $(1980,1981)$ for this region of the protein. In ovine rhodopsin the corresponding three residues are reported to be Ser-Ser-Ser. In view of the homology of the remainder of the sequence of the $C$-terminal regions of the two proteins, this difference in a region of such importance is of particular interest. A similar conservation of the retinal-binding lysine residue at position 53 from the $C$-terminus and variation of the residues around the active site have been noted from rhodopsins from two other sources (J. B. C. Findlay, personal communication).

Identification of the region between the $M$ - and $L$-fragments

Papain-cleaved rhodopsin was carboxymethylated with iodo $\left[2,{ }^{3} \mathrm{H}\right]$ acetic acid and the mixture processed to yield the L-fragment, which was further purified by chromatography on a column of Sephadex LH-60 to yield L-fragment, which gave a single band on SDS/polyacrylamidegel electrophoresis. After further purification by h.p.l.c. the L-fragment was subjected to sequence analysis (Table 2). Initial attempts gave a poor yield of 4-NN-dimethylazobenzene thiohydantoin derivative at each turn of the sequence. It was 
considered possible that the extensive exposure of the L-fragment to formic acid, often under conditions that could promote formylation of amino groups, may have resulted in the blocking of the $N$-terminal residue. We were encouraged in this belief by Dr. J. S. Seehra, who had observed a similar phenomenon in the laboratory of Professor H. G. Khorana at the Massachusetts Institute of Technology (Cambridge, MA, U.S.A.). At his suggestion the L-fragment was treated with $200 \mathrm{mM}$ $\mathrm{HCl}$ at room temperature for $2 \mathrm{~h}$ in order to hydrolyse any $N$-formyl linkage. The pretreatment indeed resulted in the expected yield of the thiohydantoin derivative, thus providing indirect support for the above hypothesis (Table 2).

The first six cycles of the Edman degradation showed the following residues:

\section{Gln/Phe-Phe/Arg-Arg/Asn-Asn/ CmCys-Xaa/Met-Met/Val}

The sequence data were interpreted to suggest that the L-fragment consisted of two populations of peptides, arising through the cleavage of the rhodopsin chain between either residues 311 and 312 or 312 and 313 from the $N$-terminus (Fig. 7). This possibility was further examined through the determination of ${ }^{3} \mathrm{H}$-radioactivity associated with the carboxymethylcysteine residues. There are three cysteine residues in the portion of the rhodopsin molecule constituting the L-fragment (Hargrave et al., 1980), and one-third of the radioactivity associated with carboxymethylcysteine residues was released at turns 4 and 5 in the ratio of $2: 1$ (Table 2). It should be noticed that although carboxymethylcysteine was detected at the fifth cycle of the degradation, its positive identification could only be made from the radiochemical data. The data prove that the cleavage by papain, culminating in the formation of $\mathrm{M}$ - and L-fragments, occurs at peptide bonds located between residues 311 and 312 , and 312 and 313 , providing two species of L-fragment.

The cleavage profile of membrane-bound rhodopsin by papain has also been studied in a number of other laboratories (Trayhurn et al., 1974; Pober \& Stryer, 1975; van Breugel et al., 1975; Albert \& Litman, 1978; Fung \& Hubbell, 1978; Zagalsky et al., 1981). The unambiguous characterization of the various domains in the three purified fragments in the present paper and, in particular, the identification of the retinal-binding site in the $\mathbf{M}$-fragment, should dispel the doubts cast on our original proposal by the results reported elsewhere (Trayhurn et al., 1974; Pober \& Stryer, 1975; Albert \& Litman, 1978; Fung \& Hubbell, 1978).

\section{A model of rhodopsin in its membrane}

In the light of the cumulative information now available, the organizational model of rhodopsin previously proposed by us (Sale et al., 1977; Mullen \& Akhtar, 1981) may be refined by ascribing the portion of the membrane-bound rhodopsin which gives rise to the L-fragment an interdiscal cytosolic location leading to the assignment of residues 311 or 312 of native rhodopsin as the $C$-terminal amino acid of the $\mathrm{M}$-fragment. The retinal-binding lysine residue at position 296 is then located in the membrane at a depth that maximally may correspond to 15 residues.

It is noteworthy that in the model for the organization of rhodopsin proposed by the Soviet group (Ovchinnikov et al., 1982) the residues 311, 312 and 313 are shown to reside in the membrane. The demonstration in the present study that the peptide bonds between these residues are easily accessible to papain cleavage should necessitate reconsideration of the assumptions underlying the prediction.

We thank the Science Research Council for a research grant, and Dr. D. P. Bloxham of this Department and Dr. J. Walker of the Laboratory of Molecular Biology, M.R.C. Centre, Cambridge, U.K., for their assistance with several problems in the general area of protein chemistry.

\section{References}

Akhtar, M., Blosse, P. T. \& Dewhurst, P. B. (1965) Life Sci. 4, 1221-1226

Akhtar, M., Blosse, P. T. \& Dewhurst, P. B. (1967) Chem. Commun. 631-632

Akhtar, M., Blosse, P. T. \& Dewhurst, P. B. (1968) Biochem. J. 110, 693-702

Albert, A. D. \& Litman, B. J. (1978) Biochemistry 17, 3893-3900

Applebury, M. L., Zuckerman, D. M., Lamola, A. A. \& Jovin, T. M. (1974) Biochemistry 13, 3448-3458

Bownds, D. (1967) Nature (London) 216, 11781181

Chang, J. Y., Brauer, D. \& Wittmann-Liebold, B. (1978) FEBS Lett. 93, 205-214

De Grip, W. J., Bonting, S. L. \& Daemen, F. J. M. (1975) Biochim. Biophys. Acta 396, 104-115

Findlay, J. B. C., Brett, M. \& Pappin, D. J. C. (1981) Nature (London) 293, 314-316

Findlay, J. B. C., Moore, A. \& Pappin, D. J. C. (1982) FEBS Lett. 138, 67-70

Fung, B. K.-K. \& Hubbell, W. L. (1978) Biochemistry $17,4396-4402$

Hargrave, P. A., Fong, S.-L., McDowell, J. H., Mas, M. T., Curtis, D. R.; Wang, J. K., Juszczak, E. \& Smith, D. P. (1980) Neurochemistry 1, 231-244

Mullen, E. (1982) Ph.D. Thesis, University of Southampton

Mullen, E. \& Akhtar, M. (1981) FEBS Lett. 182, 261-264

Mullen, E., Gore, M. G. \& Akhtar, M. (1979) Biochem. J. 183, 175-178

Mullen, E., Johnson, A. H. \& Akhtar, M. (1981) FEBS Lett. 130, 187-193 
Ovchinnikov, Y. A., Abdulaev, N. G., Feigina, M. Yu, Artamonov, I. D., Zolotarev, A. S., Kostina, M. B., Bogachuk, A. S., Miroshnikov, A. I., Martnov, V. I. \& Kudelin, A. B. (1982) Bioorg. Kim. 8, 1011-1014

Pellicone, C., Bouillon, P. \& Virmaux, N. (1980) C.R. Hebd. Séances Acad. Sci. Ser. D 290, 567-569

Pellicone, C., Bouillon, P., Virmaux, N. \& Vincendon, G. (1981) Biochimie 63, 671-676

Pober, J. S. \& Stryer, L. (1975) J. Mol. Biol. 95, 477-481

Sale, G. J., Towner, P. \& Akhtar, M. (1977) Biochemistry 16, 5641-5649

Sale, G. J., Towner, P. \& Akhtar, M. (1978) Biochem. J. $175,421-430$
Swank, R. T. \& Munkres, K. D. (1971) Anal. Biochem. 39, 462-477

Towner, P., Sale, G. J. \& Akhtar, M. (1977) FEBS Lett. 76, 51-55

Trayhurn, P., Mandel, P. \& Virmaux, N. (1974) FEBS Lett. 38, 351-353

van Breugel, P. J. G. M., Daemen, F. J. M. \& Bonting, S. L. (1975) Exp. Eye Res. 21, 315-324

Wang, J. K., McDowell, J. G. \& Hargrave, P. A. (1980) Biochemistry 19, 5111-5117

Zagalsky, P. F., Virmaux, N. \& Mandel, P. (1981) Exp. Eye Res. 32, 627-633 